\title{
NEW COMMUNICATION TECHNOLOGIES AS A SOURCE OF WESTERN CULTURAL IMPERIALISM IN NIGERIA: A STUDY OF AWKA METROPOLIS IN ANAMBRA STATE
}

\author{
Adaobi Olivia Okeke \\ Department of Mass Communication, \\ NnamdiAzikiwe University, Awka \\ findolivia2k3@gmail.com \\ Chibuike Julius Nwosu \\ Department of Mass Communication, \\ NnamdiAzikiwe University, Awka \\ nwosujuliusc@yahoo.com
}

\begin{abstract}
This study aimed at investigating new communication technologies as a source of western cultural imperialism in Nigeria; a study of Awka metropolis in Anambra State. Anchored on the framework of the Social Learning Theory, it delved into investigating the nature and the extent of domination using a survey of 100 respondents from Awka metropolis in Awka South local government area of Anambra State. The study adopted Survey method as the research design. A sample of 100 respondents were selected via the multi-stage approach. Data analysis was quantitative using simple percentages and Pearson's Chi square test. Findings indicate that residents of Awka metropolis are adequately exposed to these new electronic communication technologies and that these technologies are potential channels for foisting western (and in particular American) culture on the people while possibly eroding the indigenous culture. For this reason, it is recommended among others that Nigeria should adopt protectionism (a system of using legal mechanisms to regulate media content so as to guard against domination) as a means of controlling western cultural imperialism.
\end{abstract}

Key Words: New media, Domination, American culture, Media Imperialism

\section{INTRODUCTION}

New electronic technologies refer to those electronic tools employed for the purpose of message dissemination, reception and exchange (Langley, 1986; p.232). The history of these technologies dates back to the $19^{\text {th }}$ century when scientists began to make significant breakthroughs in electronically assisted distant communication (both wireless and otherwise). By the turn of the $20^{\text {th }}$ century, so much has been achieved that information sharing in the world now has come to rely so much on the power of electronics and telecommunication principles (Agba, 2002). The implication becomes that information power increasingly derives from technological power; he who has the technology has the information power.

Expectedly, the uneven distribution of technological power among nations of the world would necessarily imply uneven distribution of information power among these nations. Thus, the world becomes polarized into "information haves" and "information have nots". What then results is what has been termed media imperialism. Defining this, Wole$\mathrm{Abu}(2018)$ writes that media imperialism is "a process whereby ownership,structure, distribution, or content of the media of anyone country singly or together subject to the external pressure from the media interests of any other country or countries without a commensurate reciprocation in impact by the country so affected." 
DOI: doi.org/10.47851/naujocommed.v2i1.115

Being that information is culture-based; this situation gives birth to the phenomenon of cultural imperialism as there exists imbalance in the amount of information flowing between the two classes of nations mentioned above. Put differently, by way of unevenness in information flow, these more privileged nations enjoy domination over the less privileged ones in terms of exchange of culture.

Among countries of the West which have subjected Africa and the Third World to this media-based cultural domination is the United States of America who because of her technological cum economic superpower status stands out as the primus inter pares - first among equals. Therefore, in terms of who dominates the world culturally through information strength, the US is the most prominent, hence the logic behind the fear that the world is turning to an American Village.

The West is getting more sophisticated each passing day in their capacity to propagate their culture globally through the new electronic technologies which find ready market in Africa and other Third World nations (Agba, 2002). The latter's incapacity to develop these technologies locally is their weakest point in this global culture "war". Added to this is their lack of self-sufficiency in local content production, thus yielding their local media to foreign content of all kinds.

Against this background, this research investigated the extent and in what manners Nigerians have been affected by the apparent ongoing shift from a heterogeneous world to an American Village.

\section{STATEMENT OF PROBLEM}

The fact that the West has continued to dominate the global information and entertainment space due to her technological and economic superiority has abandoned a Third World nation like Nigeria to a status of an information (and by implication) cultural consumer. The distinct cultural identity of the people is increasingly being jeopardized. Cultural debates that revolve around globalization and ICTs are always disputed and emotionally laden. (Ekeanyanwu\&Edewor (2009)

Secondly, with the increasing availability and accessibility of the new electronic communication technologies of the West in a Third World country like Nigeria, the fear of American hegemony becomes more real. A study by Nnanna (2010) found that approximately $69 \%$ of university undergraduates in Lagos use the Internet; $47 \%$ of .them have regular sources of viewing foreign television stations and $71 \%$ of them have access to personal media gadgets like Media Player (MP), video and audio players, iPod and smart phones, among others. These gadgets, other things being equal, could increase the chances of exposure to Western (American) cultural elements and the attendant danger of alienation from the local culture. These problems necessitated this study.

\section{OBJECTIVES OF THE STUDY}

The purpose of this study was to investigate the extent to which residents of Awka metropolis have been affected by the 'Americanization' which the new electronic technologies have seemingly imposed on our world. In specific terms, the study aims to achieve the following objectives:

i. To find out how exposed residents of Awka metropolis are to American culture through the new electronic communication technologies. 
DOI: doi.org/10.47851/naujocommed.v2i1.115

ii. To find out whether residents of Awka metropolis are tending to view their own culture as inferior or less desirable to that of America.

iii. To find out which specific areas of life residents of Awka metropolis may have tended to imitate the American way of life.

iv. To find out whether there is $a$ relationship between the residents' exposure to the new electronic communication technologies and their tendency to adopt the American way of life.

\section{RESEARCH QUESTIONS}

The study sought answers to the following research questions:

i. How exposed are residents of Awka metropolis to American culture through the new electronic communication technologies?

ii. Are residents of Awka metropolis tending to view their own culture as inferior or less desirable to that of America?

iii. In which specific areas of life have residents of Awka metropolis tended to imitate the American way of life?

iv. Is there a relationship between the residents' exposure to the new electronic communication technologies and their tendency to adopt the American way of life?

\section{LITERATURE REVIEW}

\section{Information technologies and Cultural imperialism}

Many studies have shown how globalization came into Africa through slavery and colonialism which led to heavy loss in terms of human and material resources to Africa, (Ezema, 2010). The present day globalization is moved by information which is described by most communication scholars as the vehicle through which culture is conveyed from one generation to another. This means that with the new information domain that is information without borders, the rate at which culture is conveyed from one place to another has escalated considerably. The consequence is that countries with superior digital power are indulged by the new information terrain. Hence, the transfer of cultural information does not happen on a level-playing ground. Africa therefore, continues to stay at the receiving end. Wole-Abu (2018) described Cultural imperialism as "the practice of advancing, recognizing, dividing or artificially injecting the culture or language of one country into another. It is mostly the case that the former is a massive economically and militarily powerful country while the latter is a trifling, insignificant one." Adeniyi (2006) asserts that cultural imperialism may involve forceful imposition of a specificculture on a people or deliberate and steady embracing of foreign culture by individuals. Africa has indicted America and Europe of utilizing the sphere of globalization to force their culture on frail countries. Nevertheless, the West insists that globalization is set to eradicate not only cultural barriers but most of the negative elements of culture.

The threat of cultural erosion continually confronting Nigeria in the face of the West's technological and economic superiority has come under continuous scholarly investigations. Nnanna (2010) discovers that undergraduates in Lagos who are heavily exposed to the Western media content have tended to develop preference for the Western way of life. The study further finds that majority of the undergraduates who constantly listen to American music indicated their desire to learn and perfect American intonation.

Studies by Olagunje and Labaika (2007) and Falaye (2009) found out that children who view local films that portray foreign culture tend to imitate actions seen in such films. These 
DOI: doi.org/10.47851/naujocommed.v2i1.115

actions include the manner of speaking and dancing. The study by Falaye was anchored on the social learning theory of Albert Bandura and it "reinforced the postulation of the theory that people, particularly, children learn by observation and imitation" (Falaye, 2009).

In their study of how much the Internet has contributed to cultural invasion in Nigeria, Nwosuand Anyanwu (2009) find a correlation between Internet use and awareness of Western culture among youths. The study, however, finds no support for the notion that heavy use of the NET would bring about alienation from the indigenous culture. The researchers conclude that the cultural impact of such use would, to a significant extent, depend on other variables surrounding a particular user at any point in time.

According to Adeniyi (2006), the claim that exposure to Western media content and culture would bring about erosion of indigenous culture would only be safely made when one has put into consideration all relevant variables. He noted that cultural invasion through the media happens definitely only when the media message communicated has been effective; in other words, cultural invasion is a form of media effect. And studies spanning decades have shown that media effect do not occur in a vacuum but subject to a wide range of interferences; it is a complex process requiring some rigorous investigation to comprehend and control.

This situation, Adeniyi goes on, explains why studies on media cultural invasion have failed to yield uniform results as to the extent and nature of the media's role as a cultural imperialism tool. Thus, while studies like Nnanna (2010), Olagunje and Labaika (2007) and Falaye (2009) tend to show correlation between exposure to the Western media content and cultural invasion, studies byNwosu and Anyanwu (2009) and Adamu(2010) fail to assert such.

\section{THEORETICAL FRAMEWORK}

The Theory of Social learning offers an apt theoretical background for this study.The social learning theory is an attempt to demonstrate how individuals acquire knowledge and character within their environment through observing and imitating others. The theory was derived first and foremost from the work of Gabriel Tarde (1843-1904), but was later developed by Julian Rotter (1954), and then Albert Bandura (1977). According to Ormrod (1999), the theory focuses on the learning that occurs within a social context. It holds that as people exist and interact in the society, they learn from one another. Albert Bandura proposes that this (social) learning occurs through four main stages of imitation:
- $\quad$ Close Contact
- Imitation of Superiors
- $\quad$ Understanding of Concepts
- $\quad$ Role Model Behavior ("Social learning theory", 2011).

Within the framework of this theory, it becomes logical to expect that with exposure to Western (American) content through the new electronic technologies, Nigerians could, other things being equal, begin tomodel their lives on the behaviour and standards portrayed therein.

\section{METHODOLOGY}

Given the nature of the study, the researchers chose sample survey as the design. Sample survey allows a researcher to study a part (sample) of a given population and then generalize the result to the entire population. In survey, the "researcher is interested in observing what is happening to sample subjects or variables without any attempt to manipulate them" (Asika, 
DOI: $\underline{\text { doi.org/10.47851/naujocommed.v2i1.115 }}$

1991,p.29).The area of study was Awka metropolis in Awka South local Government Area of Anambra State.The population of study was residents of Awka with population figure of 133, 934, according to the data obtained from the 2006 national population census. The population is multi-strata, encompassing people of varying educational and vocational backgrounds.

The researcher's sample size was 100. The sampling procedure was multi-stage technique which involves following a series of logical steps in selecting sample units. Here, the researchers conducted their sampling in three stages. At the first stage, the researchers began by choosing five out of the 33 villages in Awka. The selection was made using the simple random technique which involves the application of computer-generated table of random numbers. At the second stage, the researchers chose two kindredfrom each of the five villages, making 10 kindred in all. At the third stage, the researcher chose two extended families from each of the 10 kindred, which amounted to 20 extended families in all. At the last stage, the researcher chose five persons from each of the 10 extended families using purposive sampling technique. This eventually yielded the sought 100 respondents. . The four stages are illustrated in the table below.

Table 1: SamplingStages

\begin{tabular}{|l|l|l|}
\hline Stages & Selections & Total \\
\hline 1 st Stage & 5 Villages from Awka & $5 \times 1=5$ Villages \\
\hline 2nd Stage & 2 Kindredfrom Each of the 5 Villages & $2 \times 5=10$ Kindred \\
\hline $3^{\text {rd }}$ Stage & 2 Extended Families from each of the 10 Kindred. & $2 \times 10=20$ ExtendedFamilies \\
\hline 4 th Stage & 5 Respondents from each of the 20 Extended Families & $5 \times 20=100$ Respondents. \\
\hline
\end{tabular}

The data collection instrument was questionnaire. The questionnaire comprised entirely close-ended questions. The questions were framed in a manner that supplied answers to the research questions. A set of questions were designed to relate to particular research questions. The questionnaire had three sections with Section I on questions seeking the respondents' personal data, while other sections had questions aimed at answering the research questions. To test the validity and reliability of the instrument, the researchers conducted a pilot study using 10 respondents randomly selected from the population. The instrument was administered to the respondents who filled and returned them. Analysis of their answers convinced the researchers of the instrument's validity.

Method of data analysis was quantitative. Answers extracted via the questionnaire were recorded as numeral data. The frequency and percentage was computed accordingly. Statistical tables were used topresent these data before the researcher proceeded to interpretthem towards answering the research questions. Furthermore, the Pearson's ChiSquare Test was used for testingthe relationship between exposure to American content and tendency to adopt American way of life.

\section{DATA PRESENTATION AND ANALYSIS}


DOI: $\underline{\text { doi.org/10.47851/naujocommed.v2i1.115 }}$

The data extracted from the questionnaire were presented using statistical tables. The four research questions formulated for the study were answered by interpreting the data so presented. Thereafter, the data were analyzed and discussed.

Table 2: Response Rate

\begin{tabular}{|l|l|l|}
\hline Items & Frequency & Percentage \\
\hline Number Returned & 96 & $96 \%$ \\
\hline Number Not Returned & 4 & $4 \%$ \\
\hline TOTAL & $\mathbf{1 0 0}$ & $\mathbf{1 0 0 \%}$ \\
\hline
\end{tabular}

Data in Table 2 show that of 100 questionnaire copies distributed, 96 were returned while 4 were not. Thus, $96 \%$ response rate was recorded as against $4 \%$ casualty rate.

Table 3: Sex of the Respondents

\begin{tabular}{|l|l|l|}
\hline Items & Frequency & Percentage \\
\hline Males & 41 & $42.7 \%$ \\
\hline Females & 55 & $57.3 \%$ \\
\hline TOTAL & $\mathbf{9 6}$ & $\mathbf{1 0 0 \%}$ \\
\hline
\end{tabular}

Table 3 shows that $42.7 \%$ of the respondents are males while $57.3 \%$ are females. This percentage would likely generate results that would reflect the experience of both male and female segments of the population of Awka metropolis.

Table 4: AgeBracket

\begin{tabular}{|l|l|l|}
\hline Items & Frequency & Percentage \\
\hline $15-20$ & 19 & $19.8 \%$ \\
\hline $21-25$ & 11 & $21.9 \%$ \\
\hline $26-30$ & 39 & $40.6 \%$ \\
\hline $31-35$ & 2 & $2.1 \%$ \\
\hline $36-40$ & 10 & $10.4 \%$ \\
\hline $41-45$ & 4 & $4.2 \%$ \\
\hline $46-50$ & 8 & $8.3 \%$ \\
\hline Above 50 & 3 & $3.1 \%$ \\
\hline TOTAL & 96 & $100 \%$ \\
\hline
\end{tabular}

Table 4 shows that $19.8 \%$ of the respondents were $15-20 ; 21.9 \%$ were $21-25 ; 40.6 \%$ were $26-30 ; 2.1 \%$ were $31-35 ; 10.4 \%$ were $36-40 ; 4.2 \%$ were $41-45 ; 8.3 \%$ were $46-50$; while $3.1 \%$ were above 50 . The results from this table indicate that the age bracket with the highest frequency are the ages between $26-30$ and the lowest are those above 50years. This shows 
DOI: $\underline{\text { doi.org/10.47851/naujocommed.v2i1.115 }}$

that most of the respondents for this study are in their active years. This age bracket is considered appropriate for this study because studies have shown that younger individuals tend to be more interested and inclined to modern technology gadgets and are therefore more exposed to western culture which they have the tendency to imitate.

Table 5: MaritalStatus

\begin{tabular}{|l|l|l|}
\hline ITEMS & FREQUENCY & PERCENTAGE \\
\hline Single & 61 & $63.5 \%$ \\
\hline Married & 35 & $36.5 \%$ \\
\hline Total & 96 & $100 \%$ \\
\hline
\end{tabular}

Table 5 shows that $63.5 \%$ respondents were single while $36.5 \%$ were married. This table indicates that findings would likely reflect the experience of the diverse marital demographics in Awka metropolis.

Table 6: EducationalQualificationofRespondents

\begin{tabular}{|l|l|l|}
\hline ITEMS & FREQUENCY & PERCENTAGE \\
\hline First School Leaving Certificate & 23 & $24 \%$ \\
\hline SSCE/Equivalent & 36 & $37.5 \%$ \\
\hline OND/Pre-degree Diploma & 11 & $11.5 \%$ \\
\hline 1 st Degree/ HND & 21 & $21.9 \%$ \\
\hline Post-graduate Degrees & 5 & $5.2 \%$ \\
\hline Total & 96 & $100 \%$ \\
\hline
\end{tabular}

Table 6: shows that 24\% had a first school leaving certificate; $37.5 \%$ had SSCE/Equivalent; $11.5 \%$ had OND/Pre-degree diploma; $21.9 \%$ had degrees/HND, while 5.2\% had postgraduate degrees. This suggeststhat the respondents are literate and alsolikely to be knowledgeable enough to give proper insights to the subject under review.

\section{ANALYSIS AND DISCUSSION OF FINDINGS}

\section{ResearchQuestion1: How much are residents of Awka metropolis exposed to American culture through the new electronic communication technologies?}

Here the researcher aimedto find out if respondents were exposed to American culture through the modern communication technologies. The response is analyzed below.

Table7:

Respondents'ExposuretoAmericanContentThroughModernCommunicationTechnologies

\begin{tabular}{|l|l|l|}
\hline Items & Frequency & Percentage \\
\hline
\end{tabular}




\begin{tabular}{|l|l|l|}
\hline Yes & 88 & $91.7 \%$ \\
\hline No & 8 & $8.3 \%$ \\
\hline Total & $\mathbf{9 6}$ & $\mathbf{1 0 0 \%}$ \\
\hline
\end{tabular}

Table 7 shows that $91.7 \%$ claimed to be exposed to American content through the new electronic communication technologies as against $8.3 \%$ that claimed not to be exposed to the same. This indicates that more people are exposed to American contents through these modern technologies which mean that there is a tendency that a high percentage of Nigerians could adopt the American way of life. Majority of the audience members claimed to have been exposedto American content via new electronic communication technologies, while majority yet claimed that this experience happened frequently. Based on this, the answer to the first research question is that residents of Awka metropolisare much exposed to American culture through the new electronic communication technologies and have a high tendency of adopting the American way of life having been exposed adequately to it. This finding is in tandem with a previous research carried out by Nnanna (2010) who discovered that undergraduates in Lagos who are heavily exposed to the Western media content have tended to develop preference for the Western way of life. Again, to further buttress this finding, Kunnuji (2010) in his study show that young people account for a large proportion of new communications technology usage and are prone to adapting to western culture as a result of the exposure.

\section{ResearchQuestion2:Are residents of Awka metropolis tending to view their own culture as inferior or less desirable to that of America?}

Here, the researcher sought to find out if residents of Awka metropolisview their culture as inferior or less desirable to that of America.

Table 8: Respondents'ComparativeLikenessforNigerianand American Culture

\begin{tabular}{|l|l|l|}
\hline Items & Frequency & Percentage \\
\hline Nigerian & 54 & $56.3 \%$ \\
\hline American & 42 & $43.8 \%$ \\
\hline Total & 96 & $100 \%$ \\
\hline
\end{tabular}

Table 8 shows that $56.3 \%$ claimed to like Nigerian culture more while $43.8 \%$ claimed to like American culture more.Thesedata show that some of the respondents obviously have a positive disposition to American culture, however, only close to half of them appear to be more attached to it than their local culture. Consequently, the answer to the second research question is that while a remarkable portion of the residents of Awka metropolis are tending to view their own culture as inferior to or less desirable than that of America, yet even a more significant portion of the population view the local culture as more desirable.Meaning that despite the sophistication associated with the American culture, a higher percentage of respondents still value the Nigerian culture and does not view it as inferior thereby enjoying the American contents but still holding on to the Nigerian cultural values and norms. This finding goes a long way to show that despite being exposed to western culture through the 
DOI: $\underline{\text { doi.org/10.47851/naujocommed.v2i1.115 }}$

new media technologies, most Nigerians still value their culture and traditions and are not carried away by the attractiveness of the western culture. Wahab(2012) in his study asserts that the culture of a people is their identity as it gives them due recognition in the midst of western chaos. This assertion agrees with the finding above as it recognizes the fact that most respondents still view their culture as more desirable than that of the west and therefore still values their local culture regardless of their exposure to American contents.Eze(2012) in his study contradicts this finding as he found out in his research that globalization has put many Nigerians in conflicting positions over what makes up their real cultural identity. This according to him was because since many of them were made to believe that their culture was inferior to that of Americans, they abandoned their culture to assume American culture. The result was the Nigerian who is neither wholly native nor totally foreign. He is a split personality.

\section{ResearchQuestion3:In which specific areas of life have residents of Awka metropolis tended to imitate the American way of life?}

Here, the researcher wanted to find out the specific areas residents of Awka metropolistend to imitate the American way of life. Results are analysed below.

Table 9: AspectsofAmericanCulturewhich respondents' tendtoImitate

\begin{tabular}{|l|l|l|}
\hline Items & Frequency & Percentage \\
\hline Language & 54 & $42.2 \%$ \\
\hline Arts (song, dance, etc.) & 13 & $10.2 \%$ \\
\hline Dressing & 33 & $25.8 \%$ \\
\hline Morals/Values & 0 & $0 \%$ \\
\hline Manner of Speaking & 21 & $16.4 \%$ \\
\hline Manner of Greeting & 7 & $5.5 \%$ \\
\hline Total & 128 & $100 \%$ \\
\hline
\end{tabular}

Table 9 shows that language accounts for $42.2 \%$ of the aspects of American culture which the respondents claimed to tend to imitate; arts (song, dance, etc.) account for $10.2 \%$; dressing accounts for $25.8 \%$; morals/values account for $0 \%$; manner of speaking accounts for $16.4 \%$; while manner of greeting accounts for $5.5 \%$.

The above data indicate that majority of the respondents tend to imitate American culture, and that language (42.2\%), dressing (25.8\%), manner of speaking (16.4\%) and arts $(10.2 \%)$ ranked prominent among the aspects concerned. Consequently, we answer the third research question by stating that residents of Awka metropolishave tended to imitate the American way of life more precisely in the areas of language, dressing, manner of speaking and arts (song, dance, etc.). This finding is evident in the manner of dressing in manynigerian men and women which clearly shows they have adopted and imitated the mode of dressing of the Americans. Same applies totheir imitation of American accent and love for American music especially hip hop which is most popular amongst the younger generation.Eze (2012) in his study corroborates with this finding as his study found out that most Igbo people of Nigeria 
DOI: doi.org/10.47851/naujocommed.v2i1.115

prefer to use the English Language with an American assent in their normal conversations as they could hardly finish one full sentence in Igbo language without diluting it with foreign words. This indicates that they imitate the American way of life through the constant use of English Language.

Table10:

RelationshipbetweenExposuretoAmericanContentandTendencytoAdoptAmericanWayofLife

\begin{tabular}{|l|l|l|l|l|}
\hline \multirow{2}{*}{$\begin{array}{l}\text { Exposure to American } \\
\text { Content }\end{array}$} & \multicolumn{2}{|l|}{$\begin{array}{l}\text { Respondents who adopted American } \\
\text { Way of Life }\end{array}$} & $\begin{array}{l}\text { Respondents who did not adopt } \\
\text { American Way of Life }\end{array}$ \\
\cline { 2 - 5 } & Frequency & Percentage & Frequency & Percentage \\
\hline Yes & 63 & $98.4 \%$ & 25 & $78.1 \%$ \\
\hline No & 1 & $1.6 \%$ & 7 & $21.9 \%$ \\
\hline Total & 64 & $100 \%$ & 32 & $100 \%$ \\
\hline
\end{tabular}

Table 10 is a cross-tabulation showing the relationship between exposure to American content and tendency to adopt American way of life. The table shows that $98.4 \%$ of respondents who adopted American way of life were exposed to American content, while $1.6 \%$ of them were not exposed to American content.

To see whether this relationship (between exposure to American content and tendency to adopt American way of life) is significant, we employ the Pearson's Chi-Square Test using the mean values in Table 19.

$\mathrm{X}^{2}=\sum \frac{\left(0_{1}-E_{1}\right)^{2}}{E_{1}}$

$\mathrm{E}=\frac{63+1+25+7}{4}=24$

$\mathrm{X}^{2}=\left(\frac{\left(63-24^{2)}\right.}{24}\right)+\left(\frac{\left(1-24^{2}\right.}{24}\right)+\left(\frac{\left(25-24^{2}\right.}{24}\right)+\left(\frac{\left(7-24^{2}\right.}{24}\right)$

$\mathrm{X} 2=63.4+22+0+12=97.4$

Degree of Freedom - $(\mathrm{c}-1)(\mathrm{r}-1)=1$

Decision: Since $\mathrm{X}^{2} 97.4>3.841$ we reject the null at 0.05 level of significance and accept that there is a relationship between Awka residents' exposure to American content via the new electronic communication technologies and their tendency to adopt the American way of life.

\section{CONCLUSION}

This study investigated how much and in what manners the new electronic communication technologies of the West is turning the world into an American Village with particular reference to Nigerians. The study took the survey approach aimed at eliciting information from the study population regarding their exposure to the new electronic communication technologies and how these have tended to lure them towards the American way of life.

The study found out that Nigerians are adequately exposed to these technologies and that these technologies are potential channels for foisting Western (and in particular American) culture on the people while erodingthe indigenous culture. This finding corresponds with the fear of Africans and other peoples of the Third World that unless ways of countering the status quo are found, the world would end up being completely conquered 
DOI: doi.org/10.47851/naujocommed.v2i1.115

by Western hegemony. This fear is founded given that as things stand now, Western media hegemony has since been effectively enthroned, and this (media hegemony) is a veritable catalyst for the enthronement of cultural hegemony. Discussing the colonial origin of this, Agba (2002) states that after granting nominal independence to the African countries, the colonialists through the media, still controlled and maintained a form of hegemony over their erstwhile colonies. The colonialism seed had thus spread into subtle overtures and overt exploitative relations based on advantages offered from colonialism loot. What is abound today is profound western media hegemony.

Consequently, ending the Western media hegemony remains the crucial element in ending the Western (and in particular American) cultural imperialism that has been haunting Africa, the Third World and Nigeria. At this juncture it is safe to say that the findings of this study validated the Social learning theory which this study is anchored on. The theory which holds that as people exist and interact in the society, they learn from another and with time adopt each other's way of life which concurs with the finding that Awka metropolis residents tend to adopt the way of life of the western world through their interactions with them.

\section{RECOMMENDATIONS}

The following recommendations are considered relevant in the light of the findings of this research:

i, Nigeria should device ways of furthering local production of media content as a way ofcurtailing the influx of Western culture in the country via the new electronic communication technologies.

ii. The country should alsowork towards effective economic growth and industrialization which would make her reasonably self-reliant in communication technologies and thus ensure cultural identity preservation. "Although it is not an end in itself, it (industrialization) is the principal means at the disposal of these (developing) countries for obtaining a share of the benefits of technical progress" (Asante, 2005).

iii. The nation should also adopt protectionism as a means of controlling Western cultural imperialism. Protectionism is a system of using legal mechanisms to regulate media content so as to guard against domination of the same by foreign forces (Okunna, 1999, p.119).

i. Further studies should be carried out on the subject of this study, ensuring that the shortcomings in the instant study are addressed in these later studies towards ensuring more accurate results.

\section{REFERENCES}

Agba.C. (2002).International Communication; Principles, Concepts, and Issues. New Generation Books: Enugu Nigeria.

Arnold, N. (2010). "Social Research Methods. "Retrieved from http://www.socialreserchmethods.net.

Asante, S. (2005). "Adebayo Adedeji's Ideas and Approaches to African Development." In Onimode, B. and Syoge, R. (Eds.), Issues in African Development Ibadan: Heinemann.

Asika, N (1991). Research Methodology in the BehaviouralSciences.Lagos: Longman Publishers Plc.

Akuezuilo, C.\&Agu, N. (2002). Research and Statistics in Education and Social 
Volume 2 Number 1 Jan-Mar Issue

DOI: doi.org/10.47851/naujocommed.v2i1.115

Sciences. Awka: NuelCenti Press.

Bandura, A. (1977). Social Learning Theory.New York: General Learning Press.

Bandura, A. (1986). Social Foundations of Thought and Action.Englewood Cliffs, NJ: Prentice-Hall.

Ekeanyanwu,N.\&Edewor,T.(2009).Cultural implications of ICTs and Globalization in the Nigerian Society. JournalofCommunicationandResearch.Vol 1 No 2.

Eze, D. (2014). Nigeria and the Crisis of Cultural Identity in the era of Globalization.JournalofAfricanStudiesandDevelopment.Vol. 6(8) pp140-147.

Ezema,I. (2010). Globalization, Information Revolution and Cultural Imperialism in Africa.JournalofInformation,SocietyandJustice.Vol 3 No 1.January 2010, pp11-22.

Falaye, K. S. (2009). "Children, the Media and Culture: An Experimental Inquiry." Retrieved From http://www.ehow.com/list_6592126_social-learning-theory-strengthsweaknesses, html.

Fasmoudi, M. (1979). "The New World Information Order."Journal of Communication.29(2) pp. $172-185$.

Nnanna, O. (2010). "An Analysis of ICT Use Patterns Among undergraduates in Lagos State." Journal of Social Sciences2(3), pp.2 - 29.

Nwosu, I. (1990). "Toward a positive Minimal Disintegration and Interdependence Model of World Information Flow."In I. Nwosu (Ed.), Mass Communication and National Development Aba: Frontier Publishers.

Nwosu I. \&Anyanwu, G. C. (2009). "Internet and Cultural Invasion: A Survey." Journal of Social Sciences, 2(3), pp.42 - 69.

Okafor, G. O. (2002). "Communication Research." In C. S. Okunna (Ed.), Teaching Mass Communication: A Multi-Dimensional Approach. Enugu: New Generation Books.

Okunna, C, S. (1999). Introduction to Mass Communication.(Second edition), Enugu: New Generation Books.

Olagunje, A. \&Labaika, S. O. (2007)."The Relevance of 'Parental Guidance* as a Film Classification: An experimental Study of Patterns of Interpretation of Local Movies Among primary schoolchildren in Ogun State," Journal of Social Sciences, 1(1), pp. $21-49$.

Opubor, A. (1986). "Mass Media, Custodians of Culture." In O. Nwuneli(Ed.), Mass Communication in Nigeria: A Book of Readings. Enugu:Fourth Dimension.

Ormrod, J, E. (1999). Human Learning.(3rd ed.). Upper Saddle River, NJ: Prentice-Hall. 
NNAMDI AZIKIWE UNIVERSITY Journal of COMMUNICATION AND MEDLA STUDIES

Volume 2 Number 1 Jan-Mar Issue

ISSN:2756-486X (Online)

DOI: $\underline{\text { doi.org/10.47851/naujocommed.v2i1.115 }}$

Wahab, E.O.(2012). Causes and Consequences of rapid erosion of Cultural values in a traditional African Society. JournalofSocialSciences, Vol 3(2).pp 45-51.

Wole-Abu, N.(2018). Nigerian Women, Memories of the Past and Visions of the Future through the Communication Narratives of the Media.GlobalMediaJournal 2018.Pp 16-31. 